\title{
A comparison of ARMS and direct sequencing for EGFR mutation analysis and Tyrosine Kinase Inhibitors treatment prediction in body fluid samples of Non-Small-Cell Lung Cancer patients
}

\author{
Yi Liư ${ }^{*}$, Bing Liư ${ }^{\dagger}$ Xiao-Yan Li, Jian-Jie Li, Hai-Feng Qin, Chuan-Hao Tang, Wan-Feng Guo, Hai-Xu Hu, Sha Li, \\ Cui-Jing Chen, Bing Liu, Hong-Jun Gao and Xiao-Qing Liu*
}

\begin{abstract}
Background: Epidermal growth factor receptor (EGFR) mutation is strongly associated with the therapeutic effect of tyrosine kinase inhibitors (TKIs) in patients with non-small-cell lung cancer (NSCLC). Nevertheless, tumor tissue that needed for mutation analysis is frequently unavailable. Body fluid was considered to be a feasible substitute for the analysis, but arising problems in clinical practice such as relatively lower mutation rate and poor clinical correlation are not yet fully resolved.
\end{abstract}

Method: In this study, 50 patients (32 pleural fluids and 18 plasmas) with TKls therapy experience and with direct sequencing results were selected from 220 patients for further analysis. The EGFR mutation status was re-evaluated by Amplification Refractory Mutation System (ARMS), and the clinical outcomes of TKls were analyzed retrospectively.

Results: As compared with direct sequencing, 16 positive and 23 negative patients were confirmed by ARMS, and the other 11 former negative patients (6 pleural fluids and 5 plasmas) were redefined as positive, with a fairly well clinical outcome (7 PR, 3 SD, and 1 PD). The objective response rate (ORR) of positive patients was significant, 81.3\% (direct sequencing) and $72.7 \%$ (ARMS) for pleural fluids, and $80 \%$ (ARMS) for plasma. Notably, even reclassified by ARMS, the ORR for negative patients was still relatively high, $60 \%$ for pleural fluids and $46.2 \%$ for plasma.

Conclusions: When using body fluids for EGFR mutation analysis, positive result is consistently a good indicator for TKls therapy, and the predictive effect was no less than that of tumor tissue, no matter what method was employed. However, even reclassified by ARMS, the correlation between negative results and clinical outcome of TKls was still unsatisfied. The results indicated that false negative mutation still existed, which may be settled by using method with sensitivity to single DNA molecule or by optimizing the extraction procedure with RNA or CTC to ensure adequate amount of tumor-derived nucleic acid for the test.

Keywords: Body Fluids, EGFR Mutation, Direct Sequencing, ARMS, TKIs, NSCLC

\section{Introduction}

Lung cancer causes over 1 million deaths per year worldwide, making it the major source of cancer-related deaths [1].There has been progress made in therapeutic strategies for lung cancer, but the 5-year survival rate is

\footnotetext{
* Correspondence: liuyi790114@163.com; liuxq@medmail.com.cn † Contributed equally

Cancer Center of People's Liberation Army of China, Affiliated Hospital of Academy of Military Medical Sciences, Beijing 100071, China
}

still only about $15 \%$ [2]. Treatment strategies for lung cancer have changed dramatically with the recent discovery that a proportion of non-small cell lung cancers (NSCLC) harbor activating mutations in the epidermal growth factor receptor $(E G F R)$ gene $[3,4]$, and that the mutated $E G F R$ proteins are particularly susceptible to inhibition by small-molecule tyrosine kinase inhibitors (TKIs) Gefitinib and Erlotinib [5-9].

\section{() Biomed Central}

(C) 2011 Liu et al; licensee BioMed Central Ltd. This is an Open Access article distributed under the terms of the Creative Commons Attribution License (http://creativecommons.org/licenses/by/2.0), which permits unrestricted use, distribution, and reproduction in any medium, provided the original work is properly cited. 
In the 2011 Chinese edition of NCCN clinical practice guidelines of NSCLC, TKIs has been revised as first line therapy according to the latest randomized phase III studies such as IPASS, First-SIGNAL, WJTOG3405, OPTIMAL, and the presence of EGFR-activating mutation represents critical biological factor for proper patient selection [5-11]. As a result, EGFR mutations analysis has become a routine molecular test in many Chinese hospitals, and direct sequencing is the most frequently used method because it is readily available and relatively inexpensive to use as compared with assays of real-time PCR such as TaqMan probes, Amplification Refractory Mutation System (ARMS) and High Resolution Melting (HRM).

It is well known that the optimal DNA resource for EGFR mutation analysis is tumor tissue. Unfortunately, because most of the NSCLC patients were at the advanced stage and inoperable, sufficient tumor tissue was not readily available. For example, in IPASS study, only $36 \%$ (437/1217) of the patients had biopsied tissue suitable for testing, while in INTEREST study, the ratio is only $20 \%(297 / 1466)[5,12]$. On the contrary, the sampling of body fluid such as pleural fluid and plasma is usually easy, less invasive, and repeatable, which are considered to be a feasible genomic DNA resources [13-18]. Nevertheless, the mutation test procedure using body fluids still needs to be optimized, standardized and validated.

In our hospital, patients who couldn't provide sufficient tumor tissues preferred to choose body fluids for EGFR mutation analysis, but two problems were found in our practice when direct sequencing was used. The first one was that the overall mutation rate was pretty lower than the average rate of Asian ethnic detected by sequencing (30-40\%) [11], the second one was that quite a few patients response well with the TKIs therapy although their results of the mutation test are negative. We inferred that the low sensitivity of sequencing may result in the two problems. In order to verify this speculation, we selected 50 patients with TKIs therapy experience from the patients who joined the EGFR mutation analysis using body fluids, re-evaluated the EGFR mutation status of the extracted DNA by ARMS, a method with sensitivity of $1 \%$, and analyzed the clinical outcome of TKIs retrospectively.

We found that ARMS could improve the mutation detection rate and the mutation positive patients responded well with TKIs therapy, but the correlation between mutation negative patients and TKIs therapy was still unsatisfactory. The results indicate that sensitivity of the method was not all the answers for the problems. We hypothesized that, as an alternative solution, the extraction procedure of nucleic acid should also be taken into consideration. The results of this study were reported in the present manuscript.

\section{Materials and methods}

\section{Sample collection and processing}

EGFR sequencing for exon 19 and 21 is one of the routine tests for NSCLC patients who want to initiate TKIs therapy in our hospital. The informed consent was obtained from each patient prior to the test. Pleural fluid samples were used as alternative clinical specimen for patients who couldn't provide sufficient tumor tissue. For patients who couldn't provide tumor tissue and pleural fluid, plasmas were used as an alternate. DNA was extracted from $400 \mu \mathrm{L}$ supernatant of the pleural fluid or plasma by QIAamp DNA Blood Mini kit (Qiagen, Hilden, Germany) and eluted with $50 \mu \mathrm{L} \mathrm{H}_{2} \mathrm{O}$. The extracted DNA was stored at $-20^{\circ} \mathrm{C}$ until used.

EGFR exon 19 and 21 were amplified by polymerase chain reaction (PCR) using nested primer (Table 1) with Ex Taq polymerase (Takara, Tokyo, Japan). The first cycle of amplifications were performed using a $5 \mathrm{~min}$ initial denaturation at $95^{\circ} \mathrm{C}$; followed by 30 cycles of 45 $\mathrm{s}$ at $95^{\circ} \mathrm{C}, 45 \mathrm{~s}$ at $54^{\circ} \mathrm{C}$, and $1 \mathrm{~min}$ at $72^{\circ} \mathrm{C}$; and a $6 \mathrm{~min}$ final extension at $72^{\circ} \mathrm{C}$. Production of the first cycle was amplified in the secondary cycle using same condition as first one. The final products were cleared and sequenced with the internal primers using ABI PRISM 3730 DNA Analyser (Applied Biosystems, Foster City, CA, USA).

Patients were eligible for inclusion in the study for further analysis if they fit criteria as follow: (1)With definite results of sequencing; (2)The extracted DNA was of good quality and sufficient for extra test; (3) With TKIs therapy experience and corresponding evaluation. The study was approved by the ethical committees of Affiliated Hospital of Academy of Military Medical Sciences.

The patients' DNA was re-tested by using ADx EGFR Mutations Detection Kit (Amoy Diagnostics, Xiamen, China), which has received State Food and Drug

Table 1 the nested primer

\begin{tabular}{ccc}
\hline & Sense & Antisense \\
\hline 19 exon outer & AAATAATCAGTGTGATTCGTGGAG & GAGGCCAGTGCTGTCTCTAAGG \\
19 exon inner & GTGCATCGCTGGTAACATCC & TGTGGAGATGAGCAGGGTCT \\
21 exon outer & GCAGCGGGTTACATCTTCTTC & CAGCTCTGGCTCACACTACCAG \\
\hline
\end{tabular}


Administration (SFDA)'s approval for clinical usage in mainland China recently. The kit used the principle of Amplified Refractory Mutation System (ARMS) and covered the 29 EGFR mutation hotspots from exon 18 to 21 . The assay was carried out according to the manufacturer's protocol with the MX3000P (Stratagene, La Jolla, USA) real-time PCR system. A positive or negative result could be reached if it met the criterion that was defined by the manufacturer's instruction. The results of ADx-AMRS were compared with those of direct sequencing.

\section{Treatment and evaluation}

All the patients enrolled in the study had experience of TKIs therapy (Gefitinib or Erlotinib), although some of them were defined as mutation negative. The drugs were administered according to the manufacturer's instruction. TKIs therapy was not stopped until disease progression, unacceptable toxicity, or patient refusal happened (whichever was sooner). After the discontinuation of TKIs treatment, the patients were treated according to standard clinical practice at the discretion of the investigators.

Efficacy was assessed with computed tomography (CT) scans every 4 weeks until discontinuation or as clinically indicated. Responses were defined and categorized according to Response Evaluation Criteria in Solid Tumors (RECIST). All partial and complete responses were confirmed at least 4 weeks later with repeated imaging and a designation of stable disease required lack of progression for 8 weeks or more.

\section{Statistical analysis}

Samples were examined to determine whether a statistically significant difference existed regarding variations in EGFR mutations between method of DNA sequencing and ADx-ARMS by the McNemar's test. The relationship between EGFR mutation and clinical outcome was examined by Fisher's exact test. Progression-free survivals (PFS) after TKIs therapy were analyzed by the Kaplan-Meier method, and were compared between groups by the logrank test. The statistical analysis was carried out by using SAS software version 9.1.3 (SAS Institute, Inc., Cary, NC, USA).

\section{Results}

\section{Characteristics of patients and samples}

From December in 2008 to November in 2010, 220 patients joined the EGFR mutation analysis using body fluids since sufficient tumor tissues were unavailable after routine pathological examination was done. Among them, 142 were pleural fluids, and 78 were plasma. With direct sequencing, the corresponding mutation rate is $23.2 \%$ and $5.1 \%$ respectively (Table 2 ), lower than the
Table 2 Mutation rate for different kind of body fluid samples in our clinical practice using sequencing

\begin{tabular}{cccc}
\hline & Pleural fluid & Plasma & Total \\
\hline Total & 142 & 78 & 220 \\
19-del & 18 & 2 & 20 \\
L858R & 15 & 2 & 17 \\
Mutation rate (\%) & 23.2 & 5.1 & 16.8 \\
\hline
\end{tabular}

average rate of Asian ethnic detected by sequencing on tumor tissues (30-40\%) [11]. In addition, some mutation negative patients received TKIs therapy regardless the mutation status given the poor sensitivity of DNA sequencing and were found with good outcome (data not shown).

We inferred that the low sensitivity of sequencing may result in the two problems. In order to verify this speculation, we tried to re-evaluate the EGFR mutation status of the extracted DNA by ARMS, a method with sensitivity of $1 \% .50$ patients were selected from the 220 patients according to the criteria mentioned in material and method part for further analysis. The samples included 32 pleural fluids and 18 plasmas. All the patients were Chinese and at the stage of IIIB or IV. The median age was 56.2 years (range, 31-77 years), and there were 32 males $(64 \%)$ and 18 females (36\%). The histological and/or cytological diagnosis for all the patients was adenocarcinoma. All the patients were treated with TKIs and evaluated for the response, 32 patients with Partial Response (PR), 7 with Stable Disease (SD), 11 with Progressive Disease (PD).

\section{EGFR mutation status and clinical outcome}

The EGFR mutation status and clinical outcome for each patient was shown in Additional file 1. By direct sequencing, 16 samples were mutation positive and the other 34 were negative; By ADx-ARMS, 16 mutation positive and 23 negative samples were confirmed. However, 11 former negative samples (6 pleural fluids and 5 plasmas) were redefined as mutation positive. As shown in Table 3, for pleural fluid samples, ADx-ARMS was more sensitive than direct sequencing $\left(\chi^{2}=4.17 P=\right.$ 0.0412). Nevertheless, the difference disappeared for plasma (Table $4, \chi^{2}=3.2 P=0.0736$ ), which might be caused by small number of the samples.

Table 3 Statistics analysis for pleural fluid

\begin{tabular}{cccc}
\hline ADx & \multicolumn{2}{c}{ Sequencing } & Total \\
\cline { 2 - 3 } & + & - & \\
\hline+ & 16 & 6 & 22 \\
- & 0 & 10 & 10 \\
Total & 16 & 16 & 32 \\
\hline$\chi^{2}=4.17 P=0.0412$ & & &
\end{tabular}


Table 4 Statistics analysis for Plasma

\begin{tabular}{cccc}
\hline ADx & \multicolumn{2}{c}{ Sequencing } & Total \\
\cline { 2 - 3 } & + & - & \\
\hline+ & 0 & 5 & 5 \\
- & 0 & 13 & 13 \\
Total & 0 & 18 & 18 \\
\hline$\chi^{2}=3.2 P=0.0736$ & & &
\end{tabular}

In addition, the ADx-ARMS identified 2 samples with both 19 del and L858R mutation, 4 with both 19 del and T790M mutation, and 1 with both L858R and L861Q or S768I (The two spots were designed in one tube, we could not differentiate it at that time). The representative results were showed in Figure 1.

\section{Comparison of the clinical evaluation}

The comparison of the clinical evaluation was shown in Table 5. The therapeutic effect of TKIs was significant for the mutation positive patients. For pleural fluid samples, the objective response rate (ORR) of the 16 patients who were assessed as mutation positive by direct sequencing was $81.3 \%$ (13 PR, 2 SD, 1 PD), while the ORR of the 22 mutation positive patients detected by ADx-ARMS was $72.7 \%$ (16 PR, 5 SD, 1 PD), no

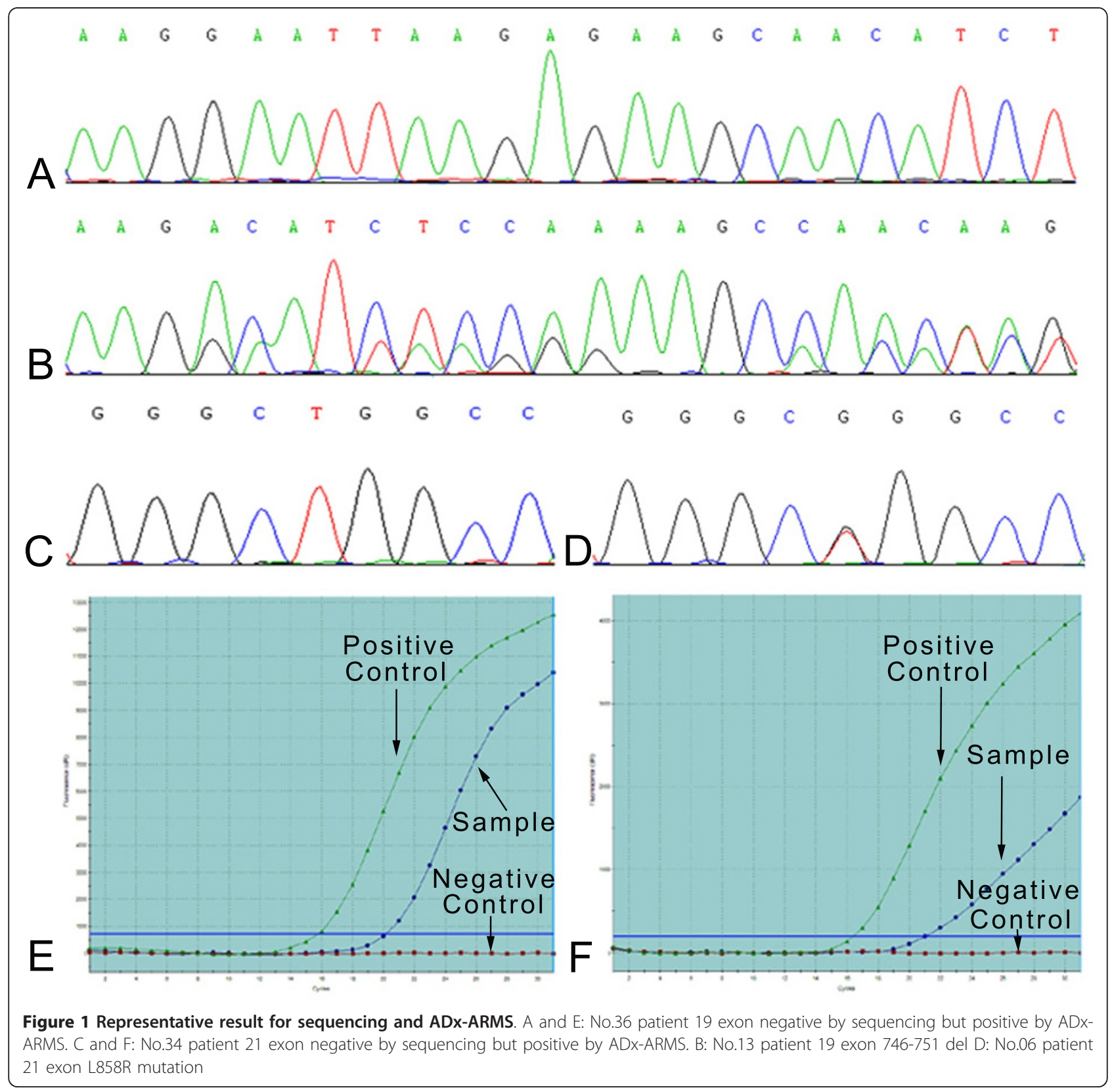




\begin{tabular}{|c|c|c|c|c|c|}
\hline & & \multicolumn{2}{|c|}{ Pleural fluid } & \multicolumn{2}{|c|}{ Plasma } \\
\hline & & Sequencing & ADx-ARMS & Sequencing & ADx-ARMS \\
\hline \multirow{5}{*}{$\begin{array}{l}\text { Mutation } \\
\text { positive }\end{array}$} & Number (\%) & $16(50 \%)$ & $22(68.8 \%)$ & 0 & $5(27.8 \%)$ \\
\hline & PR & 13 & 16 & 0 & 4 \\
\hline & SD & 2 & 5 & 0 & 0 \\
\hline & PD & 1 & 1 & 0 & 1 \\
\hline & ORR & $81.3 \%^{\mathrm{a}}$ & $72.7 \%^{\mathrm{c}}$ & NA & $80 \%{ }^{\mathrm{e}}$ \\
\hline \multirow[t]{5}{*}{ Mutation negative } & Number (\%) & $16(50 \%)$ & $10(31.2 \%)$ & $18(100 \%)$ & $13(72.2 \%)$ \\
\hline & PR & 9 & 6 & 10 & 6 \\
\hline & SD & 4 & 1 & 1 & 1 \\
\hline & PD & 3 & 3 & 7 & 6 \\
\hline & ORR & $56.3 \%^{\mathrm{b}}$ & $60 \%^{d}$ & $55.6 \%$ & $46.2 \%^{f}$ \\
\hline
\end{tabular}

$\mathrm{PR}=$ Partial Response; $\mathrm{SD}=$ Stable Disease; $\mathrm{PD}=$ Progressive Disease; ORR = Objective response rate

Between $\mathrm{a}$ and $\mathrm{b}, P=0.2524$; Between $\mathrm{c}$ and $\mathrm{d}, P=0.6828$; Between e and $\mathrm{f}, P=0.3137$; Between a and $\mathrm{c}, P=0.706$

difference was found between the two method ( $\mathrm{P}=$ 0.706). For plasma samples, because none was defined as mutation positive by direct sequencing, the ORR was unavailable. However, regarding the 5 mutation positive patients redefined by ADx-ARMS, the ORR was $80 \%$ (4 PR, 1 PD). Although the ORR of mutation negative patients seemed lower than that of mutation positive one, statistical analysis showed no difference. For pleural fluid samples with direct sequencing used, the ORR for mutation positive and negative patients was $81.3 \%$ and $56.3 \%$, respectively $(P=0.2524)$. For pleural fluids samples with ADx-ARMS used, the ORR for mutation positive and negative patients was $72.7 \%$ and $60 \%$, respectively $(P=0.6828)$. For plasma samples with ADx-ARMS used, the ORR for mutation positive and negative patients was $80 \%$ and $46.2 \%$, respectively ( $\mathrm{P}=$ $0.3137)$. Even reclassified by a more sensitive method, the ORR for mutation negative patients was still relatively high, which was $60 \%$ for pleural fluid samples and $46.2 \%$ for plasma samples. Besides, as it was shown in Additional file 2, no difference was found in progression-free survival (PFS) among mutation positive and negative patients, no matter defined by sequencing or by ARMS. These results indicated that there might still be false negative mutations in these samples.

\section{Discussion}

Although it has been well recognized that EGFR mutation is strongly associated with the therapeutic effect of TKIs in NSCLC patients, most patients could not provide the tumor tissues that needed for the mutation test $[5,12]$. Prior literatures indicate that it is feasible to use the free DNA in body fluid such as pleural fluid and plasma as alternative clinical specimen for EGFR mutation analysis [13-18], but the procedure still needs to be optimized, standardized and validated.
The major finding of our research was that, when body fluid was used as substitute for EGFR mutation detection, the positive result was a good indicator for TKIs therapy, no matter it was detected by direct sequencing or ARMS. For patients who provided pleural fluid, the ORR of the 16 mutation positive patients defined by direct sequencing was $81.3 \%$. When ARMS was used, 6 more patients were defined as mutation positive, with the ORR of the 22 patients at $72.7 \%$. For patients who provided plasma, 5 mutation positive patients were detected only by ARMS, with the ORR at $80 \%$. Generally, our result was consistent with that of OPTIMAL and IPASS research, both using tumor tissue for EGFR mutation analysis [5,9]. The ORR for mutation positive patients in OPTIMAL using direct sequencing was $83 \%$, higher than that of IPASS using ARMS strategy (71.2\%). Interestingly, such difference also occurred in our study using pleural fluid samples $(81.3 \%$ Vs $72.7 \%)$. The results implied that, more sensitive methods such as ADx-ARMS may find more positive patients, but for them, mutative cells may represent a minority of the whole tumor, which may influence the final clinical outcome of TKIs. The explanation is consistent with the work of Qing Zhou et al. which found that the relative $E G F R$ mutation abundance could predict benefit from EGFR-TKIs treatment for advanced NSCLC [19]. Our data emphasized that, for mutation positive results, the predictive effect of body fluid was no less than that of tumor tissue.

As considered for the two problems mentioned above, our research agreed with former reports that more sensitive method such as ARMS would be one of the feasible solutions $[14,20]$. Compared with direct sequencing, ADx-ARMS assay found 18.8\% (6/32) and 27.8\% (5/18) more patients to be mutation positive for pleural fluid and plasma, respectively. Direct sequencing is currently the routine method used to detect EGFR mutations. The 
merits of this method are readily available and economic, but the procedure is complicated and time-consuming. Meanwhile, the sensitivity of sequencing is about $30 \%$, which tends to cause false negative result [21]. Given the poor sensitivity of DNA sequencing, many patients and physicians opt to start TKIs treatment even if the sequencing results were negative for EGFR mutation. If the tumor does not contain activating mutations on EGFR, treatment with TKIs will most likely be ineffective. In our study, 11 former negative patients ( 6 pleural fluids, 5 plasmas) defined by sequencing were proved to be positive at last, and the clinical outcome for them was quite satisfactory. If the treatment plan was made according to the result of direct sequencing, those patients may lose the chance of TKIs therapy.

Besides, by using ARMS, we also found 7 samples which harbouring double mutations (2 patients with 19 del and L858R, 1 with L858R and L861Q or S768I, 4 with 19 del and T790M). The clinical evaluations for the former 3 patients were all PR. This result was consistent with the study of Zhang et al. [22] which showed that patients with double activating mutations involving both exons 19 and 21 tend to respond well to TKIs and the sensitivity to TKIs was enhanced compared with either single mutant. As demonstrated by Qing Zhou et al. that the relative EGFR mutation abundance could predict benefit from EGFR-TKIs treatment [19], we hypothesized that the clinical benefits (3PR, 1SD) of the 4 patients which harbouring both $19 \mathrm{del}$ and T790M may be owing to the dominant composition in 19 del.

Notably, even reclassified by ARMS, no difference was found in PFS among mutation positive and negative patients, the ORR for negative patients was still relatively high, $60 \%$ for pleural fluids and $46.2 \%$ for plasma, higher than that of IPASS (1.1\%) and First-SIGNAL (25.9\%) research $[5,6]$. Taking into consideration that all the patients in our research were adenocarcinoma, the well known type of lung cancer that can get maximum benefit from TKIs therapy, and the low abundance of DNA in body fluid, the results indicated that there might still be false negative mutations in these samples. We presumed that the phenomenon can be explained in two aspects.

Firstly, the sensitivity of ARMS is $1 \%$, nevertheless, if the abundance of the mutation DNA was below this limitation, false negative results were inevitable. Prior literature indicated that, using ARMS for plasma samples, the false negative rate was still relatively high, which was about $30 \%$ as compared with tumor tissue $[13,23]$. Recently, Yung TK et al. reported a method named Microfluidics Digital PCR, which could detect a single-mutant DNA molecule and precisely determine the quantities of mutant and wild-type sequences. By using this method, the sensitivity and specificity of plasma EGFR mutation analysis reached 92\% and 100\% respectively, as compared with the sequencing results of tumor samples [18]. This method may be more suitable than ARMS for EGFR mutation analysis using body fluid samples, but it is not readily available now and more stringent clinical evidence is still needed in the future.

Secondly, regardless of the sensitivity of detection method, if tumor-derived DNA was not contained in the body fluid sample, the mutation analysis was obviously in vain.

For pleural fluid samples, it is well recognized that cell pellets could be used to ensure tumor cells was contained in the sample. Nevertheless, in a significant proportion of patients (30-40\%), the yield of malignant cells from thoracentesis is inadequate for cytological and molecular diagnostic testing. We used cell-free pleural fluids in this study because it is abundant. Meanwhile, prior literature demonstrated that when sensitive genotyping assays was used, cell-free pleural fluid could provide the same mutational information as pleural effusion cells [15]. The problem is that, when cell-free pleural fluid was used, it was impossible to precisely evaluate whether the tumor-derived DNA was adequately contained, since the extracted free DNA arises not only from tumor cells, but also from the necrotic or apoptotic nontumor cells. Recently, free RNA in pleural fluid as a favouring material for EGFR mutation analysis was attracting more and more attention. The high EGFR mutation rate of free RNA in pleural effusion has been reported in the article by $\mathrm{Wu}$ et al. [24]. Later on, the same research group found out that the mutation-detection yield of sequencing from RNA was coupled with the superior prediction of clinical efficacy to first-line TKIs [25]. The explanation was that, contaminated nontumor cells within pleural fluid may have no or lower EGFR expression, using RNA instead of genomic DNA as the source for EGFR mutation analysis could minimize the influence of nontumor cells.

For blood samples, most reports used plasma rather than cell pellets for mutation analysis, because tumor cells in the blood are rare as compared with the cells of hematopoietic lineages. The documented sensitivity of plasma varied from $33 \%$ to $100 \%$, which may be resulted from various detection methods or from different patients enrolled $[17,18,23,26,27]$. But using plasma encounter the same problem as using cell-free pleural fluid, namely, it is impossible to precisely evaluate whether the tumor-derived DNA was adequately contained. The characterization of circulating tumor cell might resolve the problem ultimately, since it is ascertain that the test was done on tumor cells. In the study by Maheswaran et al, there were 12 patients for whom specimens of the primary tumor, CTCs, and plasma 
were all available for EGFR mutation analysis. The genotyping of CTCs appeared to be more sensitive than plasma (92\% Vs 33\%, $P=0.009$ ) [27]. The main problem now is that the technology of CTC enrichment still needs to be standardized and generalized. In recent years, tremendous efforts have been made on CTC detection and characterization [28,29]. In the near future, EGFR mutation analysis on CTC may become a reality in the routine clinical practice.

Our study had two limitations, which hindered us from verifying the hypothesis mentioned above. First, although we and others have demonstrated that body fluid is feasible [13-18], analysis for EGFR mutations with DNA extracted from tumor tissue remains the gold standard. Nevertheless, since all the patients enrolled in this study couldn't provide sufficient tumor tissue after routine pathological examination was done, the mutation status of the tumor tissue were not available and we could not testify whether there were still false negative results left after the extracted DNA were re-examined by ARMS. Second, although it is necessary to reextract the nucleic acid with an optimized procedure by RNA or CTC, and then, to compare the mutation analysis with current study, the original body fluid samples of the patients were not preserved after the mutation analysis was done, the comparison could not be carried out. In order to address the two issues above, we had set a new research plan and the patients were now under enrolling.

\section{Conclusions}

In conclusion, our finding suggested that, when body fluids were used for EGFR mutation analysis, positive result is consistently a good indicator for TKIs therapy, and the predictive effect was no less than that of tumor tissue, no matter what method was employed. Conversely, for negative result, we should be highly cautious due to its poor correlation with the response of TKIs therapy. The problem may be settled by using method with sensitivity to single DNA molecule such as Digital PCR or by optimizing the extraction procedure with RNA or CTC to ensure adequate amount of tumorderived nucleic acid for the test.

\section{Additional material}

Additional file 1: EGFR mutation status and clinical outcome for each patient. The file contains the EGFR mutation status (detected by sequencing and ARMS) and the clinical outcome (evaluation and PFS) for each patient.

Additional file 2: Kaplan-Meier analysis for PFS. The file contains Kaplan-Meier analysis for PFS in 3 categories of patients: pleural fluid samples using sequencing, pleural fluid samples using ARMS, plasma samples using ARMS.

\section{Acknowledgements}

We gratefully acknowledge the excellent statistical assistance of Bin Shan. The study was supported by Research Fund for Capital Medical Development (2007-3042) and Beijing Municipal Natural Science Foundation (7112100).

\section{Authors' contributions}

$Y L$ carried out the molecular genetic studies and drafted the manuscript. $\mathrm{BL}^{*}, \mathrm{HXH}$ and $\mathrm{SL}$ carried out the molecular analysis. BL* ${ }^{*} \mathrm{XYL}, J J \mathrm{~L}, \mathrm{HFQ}, \mathrm{CHT}$, WFG, CJC and HJG provide the body fluid samples and clinical data of the patients. $Y L, B L$ and $X Q L$ participated in the design and coordination of the study. All authors reviewed the draft manuscript and read and approved the final version for submission

\section{Competing interests}

The authors declare that they have no competing interests.

Received: 18 October 2011 Accepted: 6 December 2011 Published: 6 December 2011

\section{References}

1. Jemal A, Siegel R, Xu J, Ward E: Cancer Statistics, 2010. CA Cancer J Clin 2010, 60:277-300.

2. American Cancer Society: Cancer Facts \& Figures 2010. Atlanta: American Cancer Society; 2010

3. Paez JG, Jänne PA, Lee JC, Tracy S, Greulich H, Gabriel S, Herman P, Kaye FJ, Lindeman N, Boggon TJ, Naoki K, Sasaki H, Fujii Y, Eck MJ, Sellers WR, Johnson BE, Meyerson M: EGFR mutations in lung cancer: correlation with clinical response to gefitinib therapy. Science 2004, 304:1497-1500.

4. Lynch TJ, Bell DW, Sordella R, Gurubhagavatula S, Okimoto RA, Brannigan BW, Harris PL, Haserlat SM, Supko JG, Haluska FG, Louis DN, Christiani DC, Settleman J, Haber DA: Activating mutations in the epidermal growth factor receptor underlying responsiveness of nonsmall-cell lung cancer to gefitinib. N Engl J Med 2004, 350:2129-2139.

5. Mok TS, Wu YL, Thongprasert S, Yang CH, Chu DT, Saijo N, Sunpaweravong $P$, Han B, Margono B, Ichinose $Y$, Nishiwaki $Y$, Ohe $Y$, Yang JJ, Chewaskulyong B, Jiang H, Duffield EL, Watkins CL, Armour AA, Fukuoka M: Gefitinib or carboplatin-paclitaxel in pulmonary adenocarcinoma. N Engl J Med 2009, 361:947-957.

6. Lee JS, Park K, Kim SW: A randomized phase III study of gefitinib versus standard chemotherapy (gemcitabine plus cisplatin) as a first-line treatment for never smokers with advanced or metastatic adenocarcinoma of the lung. 13th World Conference on Lung Cancer, San Francisco 2009, (abstr PRS.4).

7. Maemondo M, Inoue A, Kobayashi K, Sugawara S, Oizumi S, Isobe H, Gemma A, Harada M, Yoshizawa H, Kinoshita I, Fujita Y, Okinaga S, Hirano H, Yoshimori K, Harada T, Ogura T, Ando M, Miyazawa H, Tanaka T, Saijo Y, Hagiwara K, Morita S, Nukiwa T, North-East Japan Study Group: Gefitinib or chemotherapy for non-small-cell lung cancer with mutated EGFR. N Engl J Med 2010, 362:2380-2388.

8. Mitsudomi T, Morita S, Yatabe Y, Negoro S, Okamoto I, Tsurutani J, Seto T, Satouchi M, Tada H, Hirashima T, Asami K, Katakami N, Takada M, Yoshioka H, Shibata K, Kudoh S, Shimizu E, Saito H, Toyooka S, Nakagawa K, Fukuoka M, West Japan Oncology Group: Gefitinib versus cisplatin plus docetaxel in patients with non-small-cell lung cancer harbouring mutations of the epidermal growth factor receptor (WJTOG3405): An open label, randomised phase 3 trial. Lancet Oncol 2010, 11:121-128.

9. Zhou $C, W u$ YL, Chen $\mathrm{G}$ : Efficacy results from the randomised phase III OPTIMAL (CTONG 0802) study comparing first-line erlotinib versus carboplatin (CBDCA) plus gemcitabine (GEM), in Chinese advanced nonsmall-cell lung cancer (NSCLC) patients (PTS) with EGFR activating mutations. Ann Oncol 2010, 21:6, (suppl 8).

10. Keedy VL, Temin S, Somerfield MR, Beasley MB, Johnson DH, McShane LM, Milton DT, Strawn JR, Wakelee HA, Giaccone G: American Society of Clinical Oncology Provisional Clinical Opinion: Epidermal Growth Factor Receptor (EGFR) Mutation Testing for Patients With Advanced NonSmall-Cell Lung Cancer Considering First-Line EGFR Tyrosine Kinase Inhibitor Therapy. J Clin Oncol 2011, 29:2121-7.

11. The Chinese Edition of NCCN Clinical Practice Guidelines in OncologyNon-Small Cell Lung Cancer Guideline. 2011. 
12. Kim ES, Hirsh V, Mok T, Socinski MA, Gervais R, Wu YL, Li LY, Watkins CL, Sellers MV, Lowe ES, Sun Y, Liao ML, Osterlind K, Reck M, Armour AA, Shepherd FA, Lippman SM, Douillard JY: Gefitinib versus docetaxel in previously treated non-small-cell lung cancer (INTEREST): a randomised phase III trial. The Lancet 2008, 372:1809-1818.

13. Kimura H, Suminoe M, Kasahara K, Sone T, Araya T, Tamori S, Koizumi F, Nishio K, Miyamoto K, Fujimura M, Nakao S: Evaluation of epidermal growth factor receptor mutation status in serum DNA as a predictor of response to gefitinib (IRESSA). Br J Cancer 2007, 97(6):778-84.

14. Kimura H, Fujiwara Y, Sone T, Kunitoh H, Tamura T, Kasahara K, Nishio K: High sensitivity detection of epidermal growth factor receptor mutations in the pleural effusion of non-small cell lung cancer patients. Cancer Sci 2006, 97(7):642-8.

15. Zhang $X$, Zhao $Y$, Wang M, Yap WS, Chang AY: Detection and comparison of epidermal growth factor receptor mutations in cells and fluid of malignant pleural effusion in non-small cell lung cancer. Lung Cancer 2008, 60(2):175-82.

16. Brevet $M$, Johnson ML, Azzoli CG, Ladanyi M: Detection of EGFR mutations in plasma DNA from lung cancer patients by mass spectrometry genotyping is predictive of tumor EGFR status and response to EGFR inhibitors. Lung Cancer 2011, 73(1):96-102.

17. Bai H, Mao L, Wang HS, Zhao J, Yang L, An TT, Wang X, Duan CJ, Wu NM, Guo ZQ, Liu YX, Liu HN, Wang YY, Wang J: Epidermal growth factor receptor mutations in plasma DNA samples predict tumor response in Chinese patients with stages IIIB to IV non-small-cell lung cancer. J Clin Oncol 2009, 27:2653-9.

18. Yung TK, Chan KC, Mok TS, Tong J, To KF, Lo YM: Single-molecule detection of epidermal growth factor receptor mutations in plasma by microfluidics digital PCR in non-small cell lung cancer patients. Clin Cancer Res 2009, 15(6):2076-84.

19. Zhou Q, Zhang XC, Chen ZH, Yin XL, Yang JJ, Xu CR, Yan HH, Chen HJ, Su J, Zhong WZ, Yang XN, An SJ, Wang BC, Huang YS, Wang Z, Wu YL: Relative Abundance of EGFR Mutations Predicts Benefit From Gefitinib Treatment for Advanced Non-Small-Cell Lung Cancer. J Clin Oncol 2011, 29(24):3316-3321.

20. Ellison G, Donald E, McWalter G, Knight L, Fletcher L, Sherwood J, Cantarini M, Orr M, Speake G: A comparison of ARMS and DNA sequencing for mutation analysis in clinical biopsy samples. J Exp Clin Cancer Res 2010, 29:132.

21. Fan X, Furnari FB, Cavenee WK, Castresana JS: Non-isotopic silver-stained SSCP is more sensitive than automated direct sequencing for the detection of PTEN mutations in a mixture of DNA extracted from normal and tumor cells. Int J Oncol 2001, 18(5):1023-6.

22. Zhang GC, Lin JY, Wang Z, Zhou Q, Xu CR, Zhu JQ, Wang K, Yang XN, Chen G, Yang JJ, Huang YJ, Liao RQ, Wu YL: Epidermal growth factor receptor double activating mutations involving both exons 19 and 21 exist in Chinese non-small cell lung cancer patients. Clin Oncol (R Coll Radiol) 2007, 19(7):499-506

23. Kuang $Y$, Rogers A, Yeap BY, Wang $L$, Makrigiorgos M, Vetrand $K$, Thiede $S$, Distel RJ, Jänne PA: Non- invasive detection of EGFR T790M in gefitinib or erlotinib resistant non-small cell lung cancer. Clin Cancer Res 2009, 15:2630-6.

24. Wu SG, Gow CH, Yu CJ, Chang YL, Yang CH, Hsu YC, Shih JY, Lee YC, Yang PC: Frequent epidermal growth factor receptor gene mutations in malignant pleural effusion of lung adenocarcinoma. Eur Respir J 2008, 32(4):924-30.

25. Tsai TH, Su KY, Wu SG, Chang YL, Luo SC, Jan IS, Yu CJ, Yu SL, Shih JY, Yang PC: RNA is Favorable for Analyzing EGFR Mutations in Malignant Pleural Effusion of Lung Cancer. Eur Respir J 2011.

26. He C, Liu M, Zhou C, Zhang J, Ouyang M, Zhong N, Xu J: Detection of epidermal growth factor receptor mutations in plasma by mutantenriched PCR assay for prediction of the response to gefitinib in patients with non-small-cell lung cancer. Int J Cancer 2009, 125:2393-9.

27. Maheswaran S, Sequist LV, Nagrath S, Ulkus L, Brannigan B, Collura CV, Inserra E, Diederichs S, lafrate AJ, Bell DW, Digumarthy S, Muzikansky A, Irimia D, Settleman J, Tompkins RG, Lynch TJ, Toner M, Haber DA: Detection of mutations in EGFR in circulating lung-cancer cells. $N$ Engl J Med 2008, 359(4):366-77.

28. Pantel K, Alix-Panabières C: Circulating tumour cells in cancer patients: challenges and perspectives. Trends Mol Med 2010, 16(9):398-406.
29. Alunni-Fabbroni M, Sandri MT: Circulating tumour cells in clinical practice: Methods of detection and possible characterization. Methods 2010, 50(4):289-97.

doi:10.1186/1756-9966-30-111

Cite this article as: Liu et al:: A comparison of ARMS and direct sequencing for EGFR mutation analysis and Tyrosine Kinase Inhibitors treatment prediction in body fluid samples of Non-Small-Cell Lung Cancer patients. Journal of Experimental \& Clinical Cancer Research 2011 30:111.

\section{Submit your next manuscript to BioMed Central and take full advantage of:}

- Convenient online submission

- Thorough peer review

- No space constraints or color figure charges

- Immediate publication on acceptance

- Inclusion in PubMed, CAS, Scopus and Google Scholar

- Research which is freely available for redistribution

Submit your manuscript at www.biomedcentral.com/submit
Biomed Central 